\title{
Analysis of the Effectiveness of Mathematics Learning Using Role Playing Model on Junior High School
}

\author{
Nurliyah Nasution \\ Universitas Negeri Medan \\ Jalan Willem Iskandar Pasar V Medan \\ Indonesia \\ nurliyahnasution@gmail.com
}

\author{
Bornok Sinaga, Mukhtar \\ Universitas Negeri Medan \\ Jalan Willem Iskandar Pasar V Medan \\ Indonesia
}

\begin{abstract}
Role playing is one of the learning models that can make the students active in teaching and learning process. The aim of this research was to determine : is that effective to learn mathematics using Role Playing Model On Social Arithmetics matter which can be seen from four indicators namely: learning quality, appropriateness level of learning, incentive, and time. The type of this research was descriptive qualitative with quantitative approach. Based on data analysis which had been done to see the quality of learning in terms of learning outcomes for the average score of pretest was 49,6 and post-tes was 80,6 . The result of observation which had been made to see the indicators of the effectiveness of learning by using the Role Playing model obtained the results good and very good category. Then, it might be concluded that the average score of learning outcomes and observations were made got the good results.
\end{abstract} model

Keywords-effectiveness of learning mathematics; role-playing

\section{INTRODUCTION}

Learners basically have a unique character that requires a teacher to be more sensitive to the situation in the field. The learning process in junior high school requires teachers who are good at learning [1]. In fact school is often found by teachers who only teach by conventional methods. so students often regard mathematics as a difficult lesson It makes students feel bored and not eager in learning[2]. The result is when a teacher tests the value of most students far below the minimum mastery criteria. Though minimal mastery on learning mathematics is 65 [3]. Based on the results of interviews with one of the junior high school Yayasan Rahmat Islamiyah found information that students say that math is a complicated lesson and especially difficult to understand the story, because basically when working on the story of the students more often imagine. The character of the students in junior high school is basically they prefer to be involved in the real world while studying. One of the learning models that can make the students active in teaching and learning process is the Role playing model. Role-plays are one type of active and participatory learning activity that creates interaction between students and a simulated scenario[4]. This type is chosen by the researcher because it has the characteristics that are considered appropriate as an effective learning model to be applied, namely by mastery of learning materials through the development of imagination and appreciation of students Role playing model can make students happy in learning as well as this method has added value that is: (a) can guarantee the participation of all students and provide equal opportunities to demonstrate their ability to work together to succeed, and (b) the game is an enjoyable experience for students. Lesson learned with role playing is a dramatic activity, a small group of students, aimed to exploit some of the problems found to be observed, which would later improve understanding [5]. A lesson is said to be effective if the learning achieves a predetermined objective the effectiveness of learning consists of four indicators, namely the quality of intruction of Appency Levels of Instruments, incentives, and time (Time)[6]. To determine the effectiveness of a method can be analyzed, whether the learning model or model meets the effective criteria. Bardiyatun sya diyah (2013) on research has received a treatment that shows that the results of learning mathematics by using role playing model can achieve learning classical completeness of 85\%[7]. Masoum(2013) on research explained that using drama in mathematics education is better results traditional teaching. From this method it can be seen that there is influence to the learning result by using role playing model[8].

\section{METHOD}

The method used in this research is qualitative descriptive type. This study examines the form of activity, creativity and motivation to learn to determine the quality of learning, [9]. In this study descriptive directed to qualitative research that is describe and reveal the conditions that occur to be drawn a conclusion [11]. This research took place at Junior high school Yayasan Rahmat Islamiyah Medan in grade VII / b students, JL. Gaperta / Bakti No 25 terrain. The time of this study is estimated for one month starting from April 2014 to May 2014. The subject of this research is the students of grade 
VII / B Yayasan Rahmat Islamiyah Medan which amounts to 25 people. The object of this research is the effectiveness of student learning mathematics by using Role Playing model on social arithmetic material. The approach taken in this research is qualitative approach and quantitative approach. Qualitative approach taken to analyze the quality of learning, the suitability of learning levels, incentives and time in the learning process. Quantitative approach taken to analyze student learning outcomes using models and materials that apply. Quantitative research uses formal,standard and measurable instruments[11]. To analyze the data used descriptive statistics. The focus of the effectiveness analysis in this study is Tests and Observations.

\section{RESULT}

TABLE I DESCRIPTIVE STATISTICS

\begin{tabular}{|c|c|c|c|c|c|c|}
\hline & N & $\begin{array}{c}\text { Mini } \\
\text { mum }\end{array}$ & $\begin{array}{c}\text { Maxi } \\
\text { mum }\end{array}$ & \multicolumn{2}{|c|}{ Mean } & $\begin{array}{c}\text { Std. } \\
\text { Deviatio } \\
\text { n }\end{array}$ \\
\cline { 2 - 7 } & $\begin{array}{c}\text { Stati } \\
\text { stic }\end{array}$ & $\begin{array}{c}\text { Statis } \\
\text { tic }\end{array}$ & $\begin{array}{c}\text { Statis } \\
\text { tic }\end{array}$ & $\begin{array}{c}\text { Statis } \\
\text { tic }\end{array}$ & $\begin{array}{c}\text { Std.E } \\
\text { rror }\end{array}$ & Statistic \\
\hline Pretest & 25 & 30 & 70 & 49.6 & 1.977 & 9.887 \\
Postest & 25 & 70 & 95 & 80.6 & 1.481 & 7.405 \\
$\begin{array}{c}\text { Valid N } \\
\text { (listwise) }\end{array}$ & 25 & & & & & \\
\hline
\end{tabular}

This study was conducted with the aim to see the effectiveness of learning mathematics students on the subject of Social Arithmetic. The results obtained can be seen from table 1. In table 1 it can be seen that to know the initial condition of students understanding done by giving pretest in the table above known that the average value is still low that is 49,60. These results indicate that the students' initial understanding is still very low, the most basic student weakness is that students have not really understood the meaning of the story. Then after the learning took place by using the learning model Role Playing students again given the posttest, based on table 4.1 it can be seen that the achievement of the lowest score is 70 and the average student score is 95 . So the average class value based on posttest is 80.6. Analysis of posttest value of learners revealed that the students' mathematics learning outcomes increased. Then perform different tests to find out the students' understanding before and after learning using the Role Playing model

The result of qualitative data analysis based on observation test reveals that the learning process from the first meeting to the last meeting has always increased with the average of observations in the study are at intervals of 2.48 to 3.67 which is in very good category. as well as the appropriateness of the learning level that is the result of the curriculum and the percentage of learning itself. as for the observations made to score 3.66 means students are ready to follow the learning materials that will be taught. as for the incentives dilakuan on students to find out how much student motivation during the learning process of incentive indicators seen that the results of observations got the value of 2.99 to 3.74 in the category of good and very good. as well as on observations made to see the length of time given to the students to learn the material given by the teacher. the results of observations made from the first meeting until the third meeting continued to increase. As for the value obtained on the observation time at the first meeting got the value of 3 second meeting 3.3 and meeting third 3,66 in very good category. Based on the results of the above research, it can be concluded that the Role Playing model is effectively used on Social Arithmetic subject in class VII / B Junior high school Rahmad Islamiyah Medan. Because the Role Playing learning model requires students to be more active in the class.

\section{CONCLUSION}

Base on the above analysis can be concluded that students have difficulty in understanding the matter of the story on social arithmetic materials Actions taken to overcome the kesuliatan students used learning model in accordance with the material taught during the learning process is a model of learning role playing so that students can solve stories related problems with everyday life. Before giving the action with the model, the average score on the pretest giving of the students in class VII / B was 49.60 after the implementation of the learning by using the role playing learning model got the average of the students score on post test is 80,60. see the increase in the value of students, based on observer observations about the quality of student learning seen in terms of learning and learning outcomes is good. as well as observations on the appropriateness of the level of learning, intensive and time spent on the learning process to get good results that get the average value above 2.5 and 3.5 in both good and very good category. it makes learning very effective, so it can improve student learning result of class VII /B Junior high school Rahmat Islamiyah MEDAN. T.P 2013 / 2014..

\section{ACKNOWLEDGMENT}

The authors are grateful to the reviewers for their helpful comments. This research was supported by the Universitas Muhammadiyah Sumatera Utara ( UMSU ) Medan . and state junior high school grade one Rahmat Islamiyah.

\section{REFERENCES}

[1] Syaiful Bahri,Aswan Zain.2011, Strategi Belajar Mengajar.Jakarta: Rineka Cipta

[2] Oskar Ku, Sherry Y. Chen, Denise H. Wu, Andrew C. C. Lao and TakWai Chan. 2014, The Effects of Game-Based Learning on Mathematical Confidence and Performance: High Ability vs. Low Ability, Educational Technology \& Society, 17 (3), 65-78.

[3] Trianto,2010,Pembelajaran te.rpadu. Jakarta: Bumi aksara

[4] Peter Kilgour, Daniel R/eynaud, Maria Northcote, \& Marion Shields. 2015, Role-Playing as a Tool to Facilitate Learning, Self Reflection and Social Awareness in Teacher Education, International Journal of Innovative Interdisciplinary Research, V2 I4 Jan 2015.

[5] Prasetyo,2010, Strategi dan Model Pembelajaran.Jakarta : Alfabet

[6] Slavin.2011, Teori Efektivitas Pembelajaran.Bandung: Nusa media 
[7] Ba'diyatun sya'diyah. 2013, Efektivitas belajar matematika dengan menggunakan model role playing.Semarang: ikip PGRI Burhan Bungin, Metodologi Penelitian Kuantitatif, Jakarta: Kencana, 2006.

[8] Elahe Masoum, Mohsen Rostamy-Malkhalifeh, Zahra Kalantarnia. 2013, A Study on the Role of Drama in Learning Mathematics, International Scientific Publications and Consulting Services, doi: 10.5899/2013/metr-00016

[9] Mulyasa.2012, Kurikulum berbasis kompetensi.Jakarta: Rosda Karya

[10] Arikunto. 2006, Prosedur Penelitian.: Rineka Cipta

[11] Sukmadinata. 2012, Metode penelitian pendidikan.: Rosdakarya 